\title{
Best Interests: A Reappraisal
}

\author{
John Coggon · Søren Holm
}

Published online: 2 August 2008

(C) Springer Science+Business Media, LLC 2008

Who is properly positioned to decide what is the right thing to do in a given clinical situation, and how can the decision properly be judged? These questions underpin a constant area of concern in critical bioethical and medico-legal discourse, where there only seems to be one solid area of consensus; the medical opinion of a clinician should not be the only relevant evaluative criterion. Issues are raised regarding individual autonomy, surrounded by concerns about informed consent and decision-making capacity. And yet more controversies arise over the way forward when a person is deemed unable to decide for him- or herself. Various possibilities present themselves. In what may be taken to be the ideal, patients will have expressed their wishes in an advance directive, but there are many circumstances where this will not-even cannot-have happened. In such cases, three alternatives are generally presented [1]. First, so-called substituted judgment may be used. Here a decision-maker or decision-making body purports to justify a medical intervention by claiming to apply the judgment that the incompetent patient would have given if he or she had capacity. This approach cannot work even in theory, however, for patients who have never been competent. Second, a proxy may be nominated or deemed to be in a position to decide on behalf of an incompetent patient. Or third, a decision may be made in (what is judged to be) the best interests of the patient. Each of the three approaches is open to criticism, and none seems universally to be

\footnotetext{
J. Coggon $(\bowtie)$

School of Law, Centre for Social Ethics and Policy, and Institute for Science, Ethics and Innovation, University of Manchester, Manchester, UK

e-mail: John.Coggon@manchester.ac.uk

S. Holm

School of Law, Cardiff Centre for Ethics, Law and Society, Cardiff University, Cardiff, UK e-mail: Holms@cardiff.ac.uk

S. Holm

Section for Medical Ethics, University of Oslo, PO Box 1130, Blindern, 0318 Oslo, Norway
} 
preferred as the best means of dealing with decision-making for people without capacity. In this special issue of Health Care Analysis, we reappraise best interests as a justification for decision-making. The papers, which were originally presented at a workshop held in the School of Law at Cardiff University in April 2007, offer distinct analyses-philosophical and jurisprudential - of this basis of decisionmaking for the incompetent. The dual analytic approach affords broader insights than would be achieved by a single disciplinary perspective, and is thus of considerable value to anyone concerned with principled critiques of decisionmaking for the incompetent.

Best interests has become a familar model to health care lawyers in common law jurisdictions. Several of the papers in this collection provide analytic insights from the perspective of experts in English law. This local jurisprudential view provides a useful basis on which to found an understanding of best interests that bridges the gaps between philosophy, policy, and practice. The questions and issues raised have particular resonance in this jurisdiction, with the Mental Capacity Act 2005 (MCA) recently coming into force and thereby giving statutory force and form to the best interests test. The contributions here have, however, a much broader scope and application than the jurisdiction of England and Wales. The philosophical and legal appraisals of best interests combine to provide an important overview of the conceptual and practical matters associated with decision-making for those who are thought to be incompetent.

In the opening paper in this special issue, Søren Holm and Andrew Edgar offer a philosophical critique of best interests. Their analysis questions a view that commonly arises, which holds that there can, in logic, only be one answer to the question of what is in a person's best interests. They suggest a more pragmatic approach should be taken to law-making, and voice some concern that judges may be including values illegitimately when assessing what is the appropriate course of action in a given situation. In response, Sheelagh McGuinness explores pragmatism in law and philosophy, and argues that in fact there is a lot shared by pragmatism and the best interests standard. She suggests that, at the very least, the two share a great deal in their method.

John Coggon develops an account of best interests as presented by English law, and understandable in light of its core tenets in health care jurisprudence. He argues that the theoretical picture that emerges is philosophically and ethically defensible, and furthermore is practically useful. His argument considers fears that best interests allows too much power to be ceded to the medical profession. His assessment distinguishes the standard itself with a system that uses the standard, and concludes that any alternative system would be equally open to abuse. Murieann Quigley, in her response, urges further caution. Quigley's concern is with the power of the judiciary, and the way it has been developed in the courts. She warns not to allow one professional standard - that of physicians - to be replaced by another - that of judges.

Shazia Choudhry's paper considers the best interests standard as it has developed in family law. Although there are overlaps between family and health care law, there are distinctions too, and lessons that can be learned from these. Choudhry critically evaluates the history of the best interests test, and maps the most salient criticisms of the standard that have emerged in the family law context. She then 
considers how they might relate to best interests in health care law. Her conclusions are that specific differences in legislation mean that family and health care law will not be equally exposed to the same concerns. She asks if sufficient weight is given to the interests of the patient under the MCA, and whether an independent expert committee should assist the Court of Protection in decisions on best interests. Following Choudhry's analysis, Søren Holm reflects that indeed there is much to learn from family law experiences. He argues, however, that Choudhry's conclusions on 'welfare science' for women in family and health care law contexts might be overstated. He further suggests that 'welfare science' considerations may well seep into legal judgments in the health care context, and voices a level of scepticism at the good of having committees to assist the Court of Protection.

Focusing on mental health issues, Phil Fennell traces the law's justifications for treatments under the best interests standard, now under the MCA, and justifications under the Mental Health Acts 1983 and 2007 (MHA). Under the MHA 1983, patients can be detained and treated without consent, for their own good, or for the good of others. The MCA, by contrast, allows treatment for those who lack capacity, but only for their own good. Fennell argues that on examination, however, the best interests standard is not purely paternalistic. His analysis demonstrates the malleability of the best interests standard, which has the potential to justify a large number of "treatments" for mental disorder that many would suppose questionable. David Gurnham reflects on this room for manoeuvre in justifications for interventions provided without the patient's consent. He considers parallels with an example taken from Jane Eyre, and argues that it is appropriate that best interests should be a broad standard to afford protection to patients, provided that decisions are made with a focus firmly on the patient's social and cultural values, rather than those of medical practitioners.

Finally, Simon Woods considers best interests in the context of end-of-life care. Woods' analysis explores best interests philosophically, and results in a preference for an axiological understanding. Woods argues that whatever understanding of the good is involved in an assessment of what best serves an individual, a "global" approach is called for that fits within the idea of "the good life". Although there may be a medical perspective, which may be used to judge what is good for someone, Woods defends the individual's position as the best judge of his or her own best interests. He then contends that at the end of life these interests become of especial importance, and thus positive claims that might not ordinarily be made by patients (against clinicians' judgment) should be respected. In his response to Woods' analysis, Richard Huxtable focuses on the case of Mrs Kelly Taylor-a woman whose case provided a paradigm example of what Woods has argued for. Huxtable asks whether the "public interest" can in fact justify limits to patient freedom. He suggests that a much larger framework than might at first be thought is needed before a full ethical analysis can be made of the normative constraints of the law.

The collection of papers in this special issue can therefore be seen to bring together a wide range of perspectives on an area of continuing controversy. The reevaluation they give to best-interests, we hope, offers a useful and timely aid to analyses and studies of health care of those deemed to lack decision-making capacity. 


\section{Reference}

1. Deryck, B., \& Roger, B. (2007). Consent in the Law. Oxford and Portland, OR: Hart, chapter 4. 